\title{
Diaphragm quantitative electromyography in difficult-to-treat asthmatic patients
}

\author{
Eletromiografia quantitativa do diafragma em pacientes com asma de difícil controle \\ Marcelo R. CAETANO', Analucia A. MARANHÃO², Eduardo M. PEIXOTO³, Alexandre H. ALAMY4, Ana Paula \\ CASSETA ${ }^{5}$, Julio C. RODRIGUES FILHO²
}

\begin{abstract}
Quantitative electromyography is an important tool to evaluate myopathies, and some difficult-to-treat asthmatic patients may have a subclinical corticosteroid myopathic process, using only inhaled corticosteroid, according to some studies. In this report, diaphragm quantitative electromyography was used to evaluate asthmatic difficult-to-treat patients, comparing them with a control group. Significant differences were obtained in amplitude, duration and size index of motor unit action potentials, with lower parameters in the asthmatic patients, which may indicate a myopathic process.
\end{abstract}

Keywords: Electrodiagnosis; asthma; muscular diseases.

RESUMO

Eletromiografia quantitativa é uma ferramenta importante para a avaliação de miopatias, e alguns pacientes asmáticos de difícil controle podem ter um processo miopático subclínico, mesmo usando apenas corticosteroides inalatórios, de acordo com alguns artigos. Nesse artigo a eletromiografia quantitativa do diafragma foi usada para avaliar os pacientes asmáticos de difícil controle, comparando com um grupo controle. Diferenças significativas nas amplitudes, durações e índices de tamanho dos potenciais de unidades motoras foram encontradas, com parâmetros mais baixos nos pacientes asmáticos, o que pode indicar um processo miopático.

Palavras-chave: Eletrodiagnóstico; asma; doenças musculares.

Phrenic neuroconduction and diaphragm electromyography are important tools in the evaluation of patients with respiratory failure. Obstructive pulmonary diseases, including asthma and chronic obstructive pulmonary disease, are well-documented causes of pulmonary distress. Abnormalities in phrenic nerve compound motor action potentials' latency, amplitude and area have been reported ${ }^{1,2,3,4,5}$. Recently, Maranhão et al. ${ }^{5}$ studied difficult-to-treat asthmatic patients with phrenic neuroconduction and diaphragm quantitative electromyography (QEMG) and found reduced phrenic compound motor action potential areas and normal diaphragm QEMG, and hypothesized that some patients may have had a subclinical myopathy5.
In spite of the fact that normative studies of diaphragm QEMG have previously been published, different methods and software were selected for this trial'. Besides, to the extent of our knowledge, there is no report applying any QEMG method to study obstructive respiratory disease.

The aim of this study was to evaluate diaphragm QEMG in a group of difficult-to-treat asthmatic patients.

\section{METHODS}

Asthmatic patients were recruited from the Gaffree and Guinle University Hospital's pulmonary ambulatory service.

\footnotetext{
${ }^{1}$ Universidade Federal do Estado do Rio de Janeiro, Departamento de Neurocirurgia, Rio de Janeiro RJ, Brasil;

${ }^{2}$ Universidade Federal do Estado do Rio de Janeiro, Departamento de Tórax, Rio de Janeiro RJ, Brasil;

${ }^{3}$ Universidade Federal do Estado do Rio de Janeiro, Faculdade de Enfermagem, Rio de Janeiro RJ, Brasil;

${ }^{4}$ Neuroclass, Departamento de Neurofisiologia, Rio de Janeiro RJ, Brasil;

${ }^{5}$ Universidade Federal do Estado do Rio de Janeiro, Departamento de Cardiologia, Rio de Janeiro RJ, Brasil.
}

Marcelo R. Caetano (iD https://orcid.org/0000-0002-6458-0695; Analucia A. Maranhão iD https://orcid.org/0000-0001-7698-231X; Eduardo M. Peixoto (iD https://orcid.org/0000-0001-5699-7290; Alexandre H. Alamy iD https://orcid.org/0000-0003-1302-6704;Ana Paula Casseta iD https://orcid.org/0000-0003-2759-0074; Julio C. Rodrigues Filho iD https://orcid.org/0000-0002-6654-5869

Correspondence: Marcelo Ribeiro Caetano; Departamento de Neurocirurgia da UNIRIO; Rua Maris e Barros, 775 ; $20270-001$ Rio de Janeiro RJ, Brasil; E-mail: ribeirocaetano67@gmail.com

Conflict of interest: There is no conflict of interest to declare.

Received 01 December 2018; Received in final form 19 April 2019; Accepted 29 April 2019. 
The exclusion criteria included neurologic disorders, diabetes mellitus, or any systemic disease affecting the nervous system. From 102 asthmatic patients, 27 were classified as difficult-to-treat, five of whom were excluded due to diabetes, and two refused to participate. None of them was an active smoker. Neurological examination, with special attention to proximal muscular strength, was performed on all of them. The inclusion criteria for difficult-to-treat asthma were the requirement of treatment within the guidelines of suggested medications in the Global Initiative for Asthma, steps 4-5 for the previous year, or use of systemic corticosteroids for $50 \%$ or more in the previous year, to prevent the asthma from becoming "uncontrolled", or that remained "uncontrolled" despite this therapy.

The control group, consisting of 15 volunteers, was recruited among students and employees (with different degrees of physical activity) from the university hospital. The study was approved by the hospital ethics committee, and all participants provided their informed consent.

The QEMG was performed with a standard disposable concentric EMG needle electrode with a recording area of $0.07 \mathrm{~mm}^{2}$, diameter of $0.46 \mathrm{~mm}^{2}$, and lengths of $37 \mathrm{~mm}$ or $50 \mathrm{~mm}$ (DCN37 and DCN50, respectively; Ambu, Neuroline, Netherlands); and an EMG system (Neuro-MEP-Micro, Neurosoft, Ivanovo, Russia) with standard settings (filters, $5 \mathrm{~Hz}$ to $10 \mathrm{kHz}$ ) was used.

A needle electrode was inserted into the medial recess of the right eighth or ninth intercostal space. During slow advancement of the needle electrode through the tissues, we carefully observed and listened to the EMG signal. Rhythmic bursts of low-amplitude motor unit potentials during inspiration and absent EMG activity during expiration confirmed that the electrode tip had reached the diaphragm. At that point, with EMG activity during normal breathing, motor unit potentials were analyzed for 30 seconds by the QEMG program, and at least 20 motor unit action potentials (MUAPs) were obtained by the software program. These have not been edited, selected or deleted. Mean and outliers amplitude, duration, thickness (area/amplitude) and size index (2x log10(amp) + area/ amp) were calculated.

The QEMG process used in this study, known as multiMUAP analysis, is present in many EMG commercial systems. First, a 5-30 second EMG epoch is acquired and digitized. Next the signal is high-pass filtered or differentiated (i.e. the rate of voltage change is computed) to enhance the spike component of the signal. The MUAP activity is detected when the processed signal exceeds a threshold level. A portion of the EMG activity before and after this detection is called the template. After the templates in the signal have been identified, the first template is assigned to the "first class". The second template is compared with the first MUAP template. If it is similar, it is assigned to the first class, otherwise it becomes a template of the second class. The process is repeated until all the MUAPs have been assigned to a class. Finally, all the classes, that have more than a minimum of matched templates, are considered to comprise MUAPs valid for analysis, and at least 20 MUAPs are necessary to calculate the mean and to define the limits of outliers ${ }^{7}$. Figure 1 shows a normal MUAP.

The data was compiled into a spreadsheet using Excel (Microsoft, Redmond, Washington, USA) and analyzed by

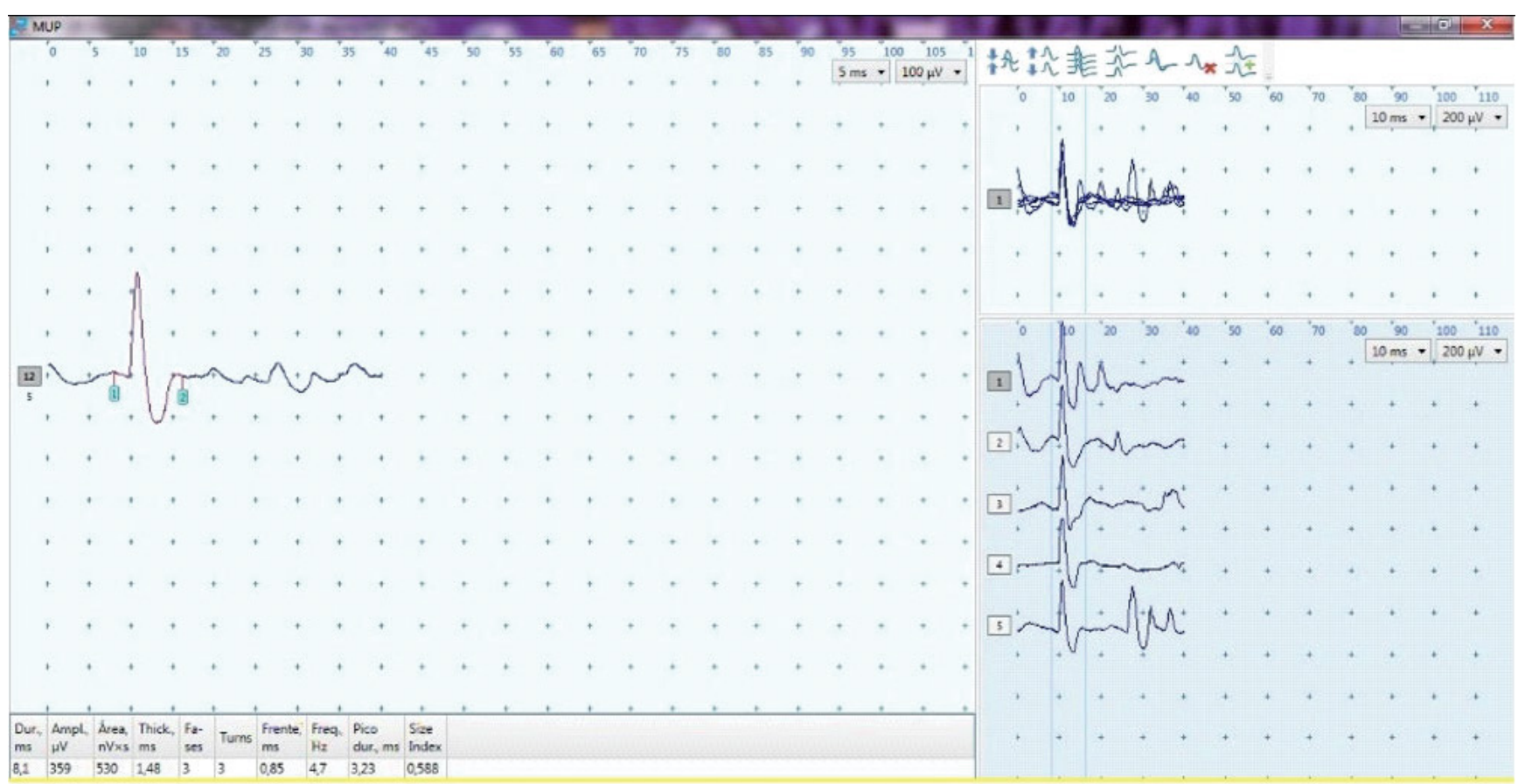

Figure 1. An example of a normal motor unit action potential (MUAP). The same stable MUAP is captured five times by the software. 
R - A Language and Environment for Statistical Computing (R Foundation for Statistical Computing, Vienna, Austria), specifically, the 'R-commander' package and its dependencies. The variables were submitted to descriptive analysis by means of frequency distribution and table of measures of central tendency and inferential analysis by means of the Kolmorogov-Smirnov and Shapiro-Wilk to consider normality in the distribution.

\section{RESULTS}

The characteristics of the 20 patients were as follows: four men and 16 women, 37-74 years old (mean 57.65 years old), height 145-170 cm (mean $158 \mathrm{~cm}$ ); weight 51-105 kg (mean $75.5 \mathrm{~kg}$ ).

The control group consisted of 15 volunteers (eight men and seven women), 21-62 years old (mean 30 years old), with no respiratory or neuromuscular disorders, all of whom had normal spirometry tests and chest X-rays. The participants' data were as follows: height 155-186 cm (mean $171 \mathrm{~cm}$ ); and weight $52-100 \mathrm{~kg}$ (mean $73 \mathrm{~kg}$ ). We noticed that the control group was significantly younger and taller than the asthmatic group.

The Table shows the inferential analysis of the two groups. Mean, interquartile range, standard deviation, and minimum and maximal values of all mean MUAP variables obtained are shown. The $5^{\text {th }}$ and $95^{\text {th }}$ percentile of all individual acquisitions were used as outlier parameters in the control group. The Table also compares these results with the asthmatic patient group. Three significant differences between the control and disease group were found: duration, size index and amplitude were considered significantly higher in the control group.

Figure 2 compares the distribution of parameters with significant differences.

\section{DISCUSSION}

Quantitative EMG is the most powerful electrodiagnostic tool to identify a myopathic process but, even with its use, corticosteroid myopathies are still a challenge to electrodiagnostic methods, as type 2 fibers are usually involved in these processes, and routine EMG almost exclusively studies type 1 fibers.

The software used in this study allowed continuous $30 \mathrm{sec}-$ onds of MUAP recording and analysis, instead of the 5 seconds allowed by other machines. This distinction offers the advantage of analyzing MUAPs during normal breathing. Podnar and Resman-Gaspersic ${ }^{6}$, in their normative study, asked normal individuals to hold a 5-second partial inspiration breath to achieve MUAP stability during these 5 seconds; otherwise the software wasn't able to identify a MUAP. But this was not feasible in some patients ${ }^{6}$. Although it is difficult or impossible to maintain a moderate sustained contraction, it is feasible to analyze $30 \mathrm{sec}-$ onds of normal breathing, to achieve at least 20 MUAPs.

Compared with Podnar and Resman-Gaspersic's ${ }^{6}$ normative study, our data was lower in all mean parameters, probably due to technical differences (breath held in partial inspiration instead of continuous normal breathing and MUAPs not being edited).

Leonardis and Podnar $^{8}$ did not find accuracy in the use of diaphragm QEMG to predict myopathy or neuropathy, but they commented that the software used and the peculiarity of myotonic dystrophy patients, may have contributed to this.

Our asthmatic patients used inhaled and or oral corticosteroids daily, possibly creating a corticosteroid myopathy.

Myopathies in asthmatic patients, who use oral steroids chronically, have also been reported in several studies. Respiratory muscle dysfunction may be manifested by difficult-to-control asthma due to decreased strength in respiratory

Table. Inferential analysis and correlation of the control and patient groups. All electrical parameters were higher in control group. The disease patient group was older and shorter compared with the control group. Amplitude and thickness, shows a non-normal distribution. Duration, index and amplitude were considered significantly higher in the control group.

\begin{tabular}{|c|c|c|c|c|c|c|c|}
\hline \multirow[b]{2}{*}{ MUAP parameters } & \multirow[b]{2}{*}{ Group } & \multicolumn{3}{|c|}{ Mean values } & \multicolumn{2}{|c|}{ Individual } & \multirow{2}{*}{$\begin{array}{c}\text { Correlation } \\
\text { (method) }\end{array}$} \\
\hline & & Mean \pm SD & IQR & Range & $5^{\text {th }}$ percentile & $\begin{array}{c}95^{\text {th }} \\
\text { percentile }\end{array}$ & \\
\hline \multirow{2}{*}{ Amplitude $(\mu \mathrm{v})$} & Control & $277 \pm 123$ & 150.2 & $89-599$ & \multirow{2}{*}{70} & \multirow{2}{*}{948} & \multirow{2}{*}{$\begin{array}{c}<0.001 \\
\text { (Wilcoxon) }\end{array}$} \\
\hline & Disease & $255 \pm 91.04$ & 112.4 & $118-520$ & & & \\
\hline \multirow{2}{*}{ Duration (ms) } & Control & $7.83 \pm 1.05$ & 1.50 & $5.66-9.54$ & \multirow{2}{*}{5.12} & \multirow{2}{*}{11} & \multirow{2}{*}{$\begin{array}{l}<0.001 \\
\text { (T test) }\end{array}$} \\
\hline & Disease & $7.25 \pm 0.83$ & .089 & $5.74-8.64$ & & & \\
\hline \multirow{2}{*}{ Area ( $\mu \mathrm{v} / \mathrm{MS})$} & Control & $375 \pm 176$ & 313.5 & $141-683$ & \multirow{2}{*}{86} & \multirow{2}{*}{1127} & \multirow{2}{*}{$\begin{array}{l}0.8336 \\
\text { (T test) }\end{array}$} \\
\hline & Disease & $340 \pm 117$ & 140.6 & $149-549$ & & & \\
\hline \multirow{2}{*}{ Thickness (ms) } & Control & $1.49 \pm 0.40$ & 0.56 & $0.87-2.26$ & \multirow{2}{*}{0.55} & \multirow{2}{*}{248} & \multirow{2}{*}{$\begin{array}{c}0.4859 \\
\text { (Wilcoxon) }\end{array}$} \\
\hline & Disease & $1.45 \pm 0.32$ & 0.55 & $1.06-2.08$ & & & \\
\hline \multirow{2}{*}{ Size index } & Control & $0.06 \pm 0.58$ & 1.07 & $-0.93-0.98$ & \multirow{2}{*}{-1.11} & \multirow{2}{*}{1.43} & \multirow{2}{*}{$\begin{array}{l}<0.001 \\
\text { (T test) }\end{array}$} \\
\hline & Disease & $0.05 \pm 0.40$ & 0.46 & $-0.66-0.82$ & & & \\
\hline
\end{tabular}

MUAP: motor unit action potential. 

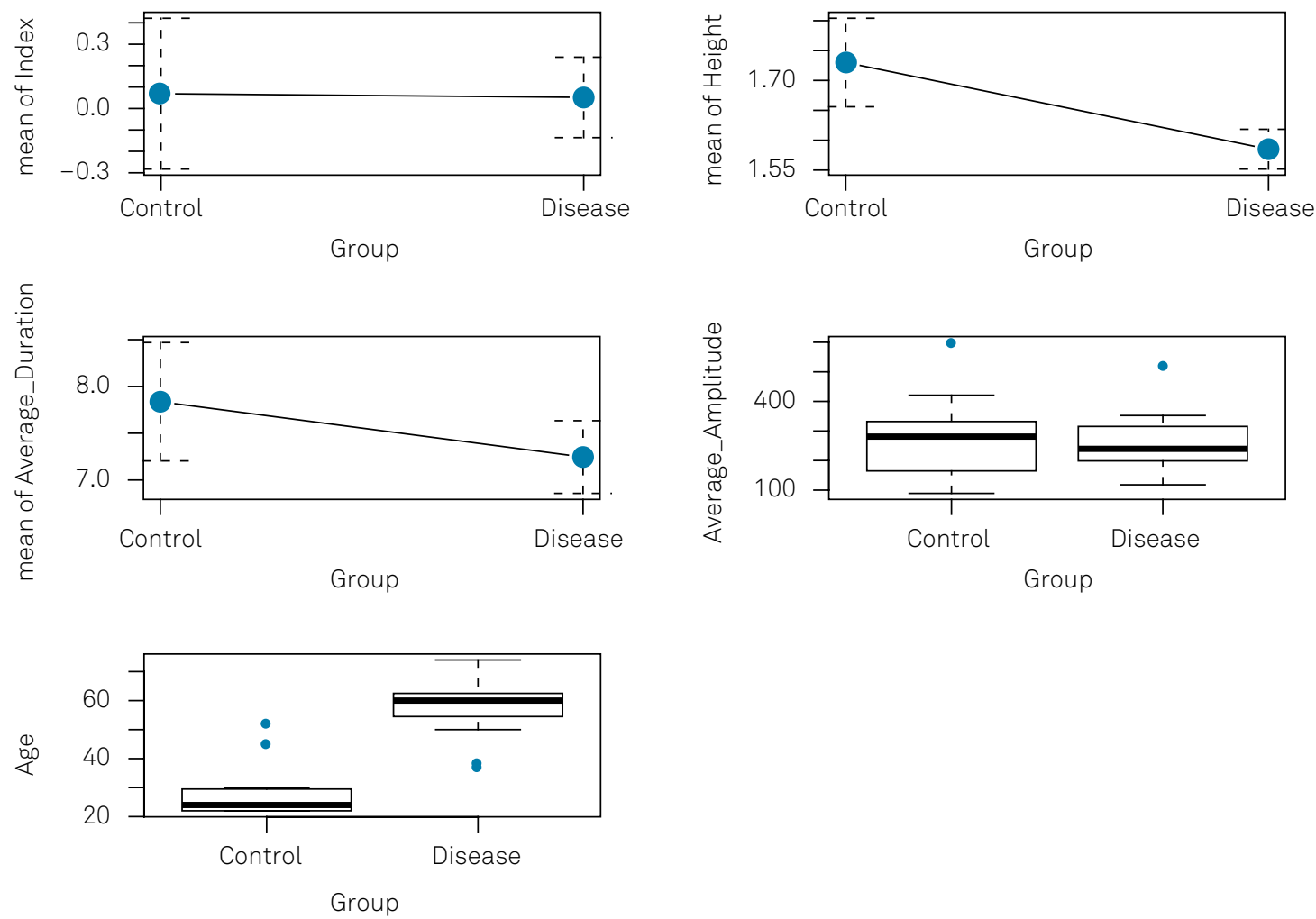

Figure 2. Comparing the distribution of parameters with significant differences. Duration, size index, height and amplitude were considered significantly higher, and age was the only parameter significantly lower in the control group.

muscles ${ }^{9}$. Decramer and Stas ${ }^{10}$ reported on patients with a significant reduction in maximum inspiratory pressure and maximum expiratory pressure due to treatment with high doses of oral corticosteroids, which improved dramatically after three months of corticosteroid withdrawal. They observed a mean reduction of $31 \%$ (16-46\%) of predicted quadriceps strength in chronic patients. The authors also reported that improved muscle strength was slower in the legs than in the respiratory muscles. Six months after reduction of corticosteroid use, the quadriceps strength ranged from $31 \%$ to $85 \%$ of normal expectation ${ }^{10}$. Minetto et al. ${ }^{11}$ described the reduction of muscle fiber conduction velocity in the vastus lateralis, vastus medialis, and anterior tibialis in patients with Cushing's disease compared with controls.

Inhaled corticosteroids are generally considered by medical pulmonologists to be safer drugs in relation to oral corticosteroids. However, some studies do not support this statement. Akkoca et al. ${ }^{12}$ reported similar impairment of respiratory muscles in patients with oral and inhaled corticosteroids. Mak et al. ${ }^{13}$ found no significant differences in quadriceps and sternocleidomastoid muscle strength among patients receiving oral and inhaled corticosteroids. In addition, four of the 12 patients who used inhaled beclomethasone versus only one of 12 taking oral prednisone had quadriceps weakness ${ }^{13}$.

Although the corticosteroid-related myopathy hypothesis may explain our findings, the lack of QEMGs in other skeletal muscles apart from diaphragm and muscle biopsy, do not allow any conclusions. In addition, the great difference between height and age between the control and disease group may have had some impact on our findings.

In conclusion, this study found significant differences in the diaphragm MUAP parameters of asthmatic difficult-to-treat patients, which may be correlated with a myopathic process, but further studies are needed to corroborate this hypothesis. Like other trials, this could prove the feasibility of diaphragm EMG as an important tool in the evaluation of the respiratory tract.

\section{References}

1. Podnar S, Harlander M. Phrenic nerve conduction studies in patients with chronic obstructive pulmonary disease. Muscle Nerve. 2013 Apr;47(4):504-9. https://doi.org/10.1002/mus.23617
2. Hopkinson NS, Sharshar T, Ross ET, Nickol AH, Dayer MJ, Porcher $\mathrm{R}$, et al. Corticospinal control of respiratory muscles in chronic obstructive pulmonary disease. Respir Physiol Neurobiol. 2004 Jul;141(1):1-12. https://doi.org/10.1016/j.resp.2004.04.003 
3. Lu Z, Tang X, Huang X. Phrenic nerve conduction and diaphragmatic motor evoked potentials: evaluation of respiratory dysfunction. Chin Med J (Engl). 1998 Jun;111(6):496-9.

4. El-Tantawi GA, Imam MH, Morsi TS. Phrenic nerve conduction abnormalities correlate with diaphragmatic descent in chronic obstructive pulmonary disease. COPD. 2015;12(5):516-24. https://doi.org/10.3109/15412555.2014.993465

5. Maranhão AA, Rodrigues MM, Carvalho SR, Caetano MR, Compagnoni IM, Carnio TK, et al. Is phrenic nerve conduction affected in patients with difficult-to-treat asthma? Arq Neuropsiquiatr. 2018 Mar;76(3):177-82. https://doi.org/10.1590/0004-282×20180010

6. Podnar S, Resman-Gaspersic A. Quantitative motor unit potential analysis in the diaphragm: a normative study. Muscle Nerve. 2008 Apr;37(4):518-21. https://doi.org/10.1002/mus.20939

7. Nandedkar SD, Stalberg E, Sanders D. Quantitative EMG. In: Dumitru D, Amata AA, Zwarts MJ, editors. Electrodiagnostic Medicine. Philadelphia: Hanley \& Belfus; 2002. pp. 296-300.

8. Leonardis L, Podnar S. Template-operated MUP analysis is not accurate in the diagnosis of myopathic or neuropathic changes in the diaphragm. Neurophysiol Clin. 2017 Dec;47(5-6):405-12. https://doi.org/10.1016/j.neucli.2017.07.003
9. Levin OS, Polunina AG, Demyanova MA, Isaev FV.

Steroid myopathy in patients with chronic respiratory diseases. J Neurol Sci. 2014 Mar;338(1-2):96-101. https://doi.org/10.1016/j.jns.2013.12.023

10. Decramer M, Stas KJ. Corticosteroid-induced myopathy involving respiratory muscles in patients with chronic obstructive pulmonary disease or asthma. Am Rev Respir Dis. 1992 Sep;146(3):800-2. https://doi.org/10.1164/ajrccm/146.3.800

11. Minetto MA, Botter A, Lanfranco F, Baldi M, Ghigo E, Arvat E. Muscle fiber conduction slowing and decreased levels of circulating muscle proteins after short-term dexamethasone administration in healthy subjects. J Clin Endocrinol Metab. 2010 Apr;95(4):1663-71. https://doi.org/10.1210/jc.2009-2161

12. Akkoca O, Mungan D, Karabiyikoglu G, Misirligil Z. Inhaled and systemic corticosteroid therapies: do they contribute to inspiratory muscle weakness in asthma? Respiration. 1999;66(4):332-7. https://doi.org/10.1159/000029403

13. Mak VH, Bugler JR, Spiro SG. Sternomastoid muscle fatigue and twich maximum relaxation in patients with steroid dependent asthma. Thorax. 1993;48(10):978-84. https://doi.org/10.1136/thx.48.10.979 